\title{
Nosography of systemic inflammatory response syndrome, sepsis, severe sepsis, septic shock, and multiple organ dysfunction syndrome in internal medicine patients
}

\author{
Silvia Spoto, Emanuele Valeriani, Sebastiano Costantino \\ Department of Internal Medicine, Campus Bio-Medico University, Rome, Italy
}

\begin{abstract}
Sepsis is defined by the presence of at least two systemic inflammatory response syndrome criteria associated with an infection microbiologically or clinically evidenced. In Italy sepsis is responsible for 80,000 hospital admissions per year and, in the last decades, severe sepsis and septic shock cases are increasing, in correlation with the increased prevalence of multi-drugresistant microbial strains. The predominant etiologic agents are Gram-positive and Gram-negative bacteria, but sepsis caused by fungi is increasing. The host response with both inflammatory and anti-inflammatory processes is responsible for organic failures, which complicate the syndrome, and for the susceptibility to secondary infections. The impairment of one or more organs or systems may be the onset clinical presentation. The organ dysfunctions complicating sepsis involve mainly cardiorespiratory system, kidneys, hemostatis and central nervous system. Fever or hypothermia, tachycardia, tachypnea, leukocytosis or leukopenia, elevated blood levels of lactate and procalcitonin, hypotension are diagnostically sensitive findings for sepsis. Definitive diagnosis requires isolation of the pathogen from blood sample or from the focus of infection. Therapeutic success against sepsis depends on the appropriate use of antibiotics, on the treatment of hemodynamic and respiratory disorder and on general supportive care. In some cases the use of activated protein $\mathrm{C}$ is to take in consideration.
\end{abstract}

\section{Introduction}

Sepsis is defined by an infection, proven (microbiologically evidenced) or clinically suspected, asso-

Correspondence: Sebastiano Costantino, Department of Internal Medicine, Campus Bio-Medico University, via Álvaro del Portillo 21, 00128 Rome, Italy.

Tel.: +39.06.22541.1899 - Fax: +39.06.22541.1953.

E-mail: s.costantino@unicampus.it

Key words: Sepsis; severe sepsis; septic shock; systemic inflammatory response syndrome; multiple organ dysfunction syndrome.

Acknowledgments: the authors thank Cecilia Di Stefano and Stefano Valeriani for translation.

Contributions: SC drafting the manuscript; SS and EV searching the references. All authors contributed to manuscript revising and approved the final version.

Conflict of interest: the authors declare no potential conflict of interest.

Received for publication: 13 May 2015.

Revision received: 26 June 2015

Accepted for publication: 26 June 2015.

This work is licensed under a Creative Commons Attribution NonCommercial 3.0 License (CC BY-NC 3.0).

(C) Copyright S. Spoto et al., 2015

Licensee PAGEPress, Italy

Italian Journal of Medicine 2015; 9:243-251

doi:10.4081/itjm.2015.606 ciated with systemic inflammatory response syndrome (SIRS) (Table 1). ${ }^{1}$

SIRS can have both infectious and non-infectious etiology (pancreatitis, burns, trauma, acute adrenal insufficiency, pulmonary embolism, dissecting or ruptured aortic aneurysm, occult hemorrhage, cardiac tamponade, anaphylaxis, drug-overdose). ${ }^{1}$

Severe sepsis is defined as sepsis complicated by hypotension and hypoperfusion and at least a sepsisinduced organ dysfunction, different from the one of primary infection (Table 1). ${ }^{2}$

Septic shock is defined as sepsis associated with arterial hypotension - systolic blood pressure (SBP) $<90 \mathrm{mmHg}$ or mean arterial pressure (MAP) $<65$ $\mathrm{mmHg}$ or decrease in SBP of $>40 \mathrm{mmHg}$ - refractory to fluid bolus infusion and which requires vasopressors (Table 1) or hyperlactatemia. ${ }^{3}$

\section{Epidemiology}

In Italy sepsis is responsible for $70-80,000$ hospital admissions per year. Severe sepsis occurs in $2.1 \%$ of all hospitalizations and septic shock in 3\%. ${ }^{4,5}$ This picture is essentially analogous to that of other Western countries: in the United States sepsis causes 2\% of hospital admissions and more than 200,000 deaths per year. ${ }^{6}$

In the last decades, the incidence of severe sepsis and septic shock has increased and nowadays in the US, it is about 300 cases per 100,000 people. $^{7}$ The increased incidence can be related to the general population's 
older age, to immunosuppression, to the increased prevalence of multi-drug-resistant microbial strains.

\section{Etiology}

Sepsis may occur in response to each type of infection (Table 2). ${ }^{8}$ However, the most frequent causes of sepsis is pneumonia. ${ }^{9}$ Bacteremia is not essential for the development of the syndrome: blood cultures yield positive results only in one third of severe sepsis' cases and in around half of septic shock's cases. ${ }^{10}$ Moreover, even if the etiologic agent can be identify by infected material cultures from a local site, one third of results from these cultures are negative..$^{11,12}$

The predominant etiologic agents are Gram-positive bacteria (Staphylococcus aureus and Streptococcus pneumoniae are the most common) and Gram-negative bacteria (Escherichia coli, Klebsiella spp., and Pseudomonas aeruginosa prevail); together, they are responsible for about $70 \%$ of sepsis. ${ }^{13,14}$ Nevertheless, sepsis caused by fungi is increasing (Table 2). ${ }^{9}$

\section{Pathophysiology}

The host responds to sepsis with inflammatory and anti-inflammatory processes in order to block the infection and to restore normal organic function. Both the inflammatory response and the anti-inflammatory one could result in being responsible for the contingent catastrophic consequences of sepsis. ${ }^{15}$ One of the inflammatory response mechanisms, oriented to pre- vent infectious spread, is intravascular thrombosis, through the promotion of tissue factor expression and the inhibition of anticoagulant pathway protein C-protein $\mathrm{S} .{ }^{16}$ On the one hand, intravascular thrombosis associated with insufficient mitochondrial oxygen consumption and production of vasodilator molecules (nitric oxide, $\beta$-endorphin, bradykinin, platelet-activating factor, prostacyclin), can cause organ damage and multiple organ failure. ${ }^{17}$ On the other hand, the anti-inflammatory response, aimed at tissue repair through neuroendocrine regulation (which induce inhibition of pro-inflammatory cytokines production), ${ }^{18}$ reduced function of immune cells and inhibitions of pro-inflammatory transcription gene- induces susceptibility to secondary infections. ${ }^{19,20}$

\section{Clinical manifestations}

It is possible that during the initial phase of sepsis the patient does not immediately satisfy the diagnostic criteria, showing normal parameters in terms of core temperature, heart rate, respiratory rate, white blood cell (WBC) count. Nevertheless, generally the patient is feverish. The absence of fever or the presence of hypothermia is more common in the elderly, in alcoholics and in newborns.

Anyhow clinical manifestations of the syndrome overlap with signs and symptoms of underlying infectious disease. However, even in these cases, physical examination can highlight physical findings and allow the classification of the responsible infection.

Delirium can be a sign of sepsis in the elderly or

Table 1. Systemic inflammatory response syndrome, severe sepsis, septic shock.

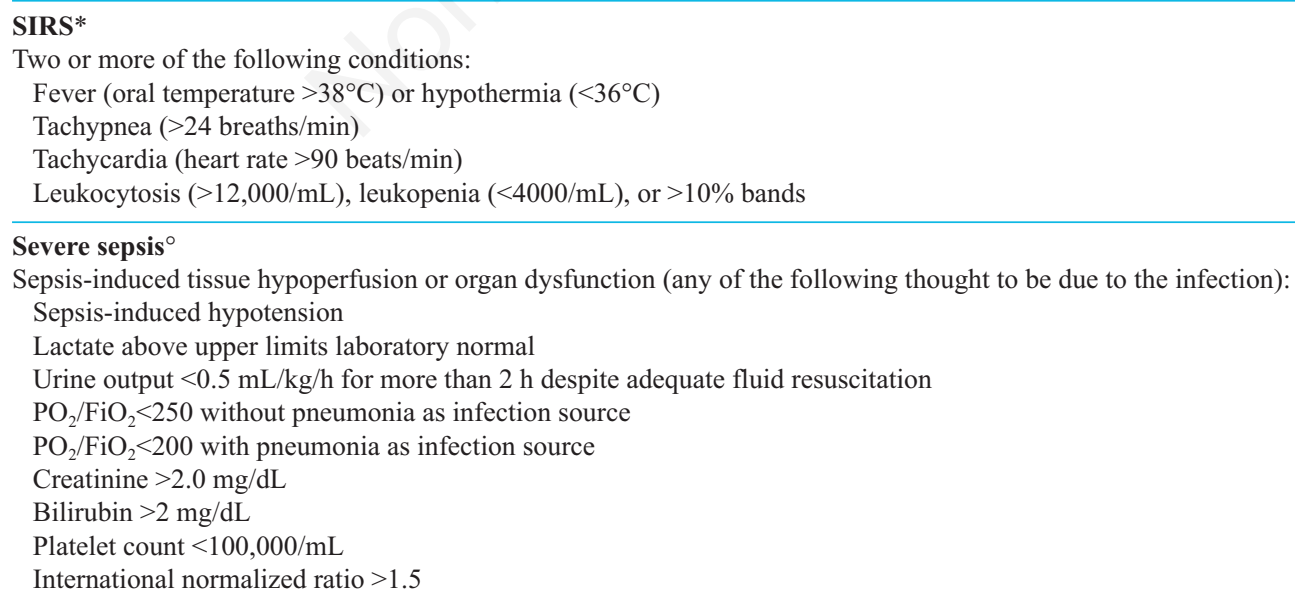

SIRS, systemic inflammatory response syndrome. *Definitions by the Consensus Conference ACCP/SCCM; ${ }^{\circ}$ Adapted from Dellinger et al., 2013; ${ }^{*}$ Adapted from Cawcutt and Peters, 2014. ${ }^{3}$ 
in a patient with a preexisting neurologic impairment. ${ }^{21}$ Acrocyanosis and ischemic necrosis of peripheral tissues are manifestations of a hemodynamic and procoagulative disorder. Other cutaneous lesions may reflect the action of bacterial toxins distributed hematogenously or the invasion of soft tissues by microorganisms themselves. ${ }^{22,23}$ A generalized erythroderma suggests a toxic shock syndrome ( $S$. aureus, Streptococcus pyogenes). Petechiae or purpura are typically associated with Neisseria meningitidis or Haemophilus influenzae infections. Generally ecthyma gangrenosum, with its typical bullous lesions, peripheral edema and necrotic center, indicates an infection caused by $P$. aeruginosa .

The impairment of one or more organs or systems may be the onset clinical presentation of sepsis syndrome. The organ dysfunctions complicating sepsis are especially against cardiorespiratory system, kidneys, hemostasis and central nervous system. ${ }^{24}$

In most cases, depression of myocardial function develops within $24 \mathrm{~h}$, but in survivors returns to normal in a few days. ${ }^{25}$

The lung is one of the organs that are compromised earlier. Hyperventilation, respiratory alkalosis and hypoxemia are manifestations often present from the start. The abnormal capillary permeability and the absorption of liquid into lung tissue are responsible for two severe complications of sepsis: acute lung injury
(ALI) and acute respiratory distress syndrome (ARDS), ${ }^{26,27}$ both with acute onset, bilateral pulmonary infiltrates, no clinical evidence of increased left atrial pressure and with $\mathrm{PO}_{2} / \mathrm{FiO}_{2} \leq 300 \mathrm{mmHg}$ (ALI) and $\leq 200 \mathrm{mmHg}$ (ARDS). ${ }^{28}$

Acute kidney injury (AKI) with oliguria and proteinuria has been observed in $50 \%$ of cases of severe sepsis and septic shock. The causes of AKI may be both pre-renal and intrinsic. Pre-renal AKI is caused by hypovolemia and hypotension; ${ }^{29}$ intrinsic AKI may be secondary to kidney ischemia, a consequence of prerenal azotemia, but also to acute tubular necrosis and to interstitial nephritis due to inflammatory damage and all consequent to a generalized prothrombotic condition.

\section{Nervous system involvement}

During sepsis the level of consciousness is often altered. The central nervous system injury process is multifactorial and depends on cerebral vascular alterations, hypoxemia and alterations in acid-base equilibrium. In patients in whom sepsis lasts for weeks may be observed a polyneuropathy due to critical illness. ${ }^{21}$

\section{Liver and gastrointestinal apparatus involvement}

Frequently the hepatic function results slightly compromised because of microvascular alterations

Table 2. Common sites of infection in patients with severe sepsis by gender. Types of organism in culture-positive infected patients.

\begin{tabular}{lcc}
\hline \multicolumn{3}{c}{ Common sites of infection in patients with severe sepsis by gender* } \\
\hline Site of infection & Frequency in male (\%) & Frequency in female (\%) \\
\hline Respiratory & 41.8 & 35.8 \\
\hline Bacteriemia, site unspecified & 21.0 & 20.0 \\
\hline Genitourinary & 10.3 & 18.0 \\
\hline Abdominal & 8.6 & 8.1 \\
\hline Device-related & 1.2 & 1.0 \\
\hline Wound/soft tissue & 9.0 & 7.5 \\
\hline Central nervous system & 0.7 & 0.5 \\
\hline Endocarditis & 0.9 & 0.5 \\
\hline Other/unspecified & 6.7 & 8.6
\end{tabular}

\begin{tabular}{lccccc}
\hline \multicolumn{5}{c}{ Types of organism in culture-positive infected patients ${ }^{\circ}$} \\
\hline Organism & Frequency (\%) & Organism & Frequency (\%) & Organism & Frequency (\%) \\
\hline Gram-positive & & Gram-negative & Anaerobes & 4.5 \\
S. aureus & 20.5 & Pseudomonas spp. & 19.9 & Other bacteria & 1.5 \\
MRSA & 10.2 & E. coli & 16.0 & Fungi & 17.0 \\
Enterococcus & 10.9 & Klebsiella spp. & 12.7 & Candida & 1.4 \\
S. epidermidis & 10.8 & Acinetobacter spp. & 8.8 & Aspergillus & 1.0 \\
S. pneumoniae & 4.1 & Enterobacter & 7.0 & Other & 0.7 \\
Other & 6.4 & Other & 17.0 & Parasites & 3.9 \\
& & & & Other organism &
\end{tabular}

*Adapted from van Gestel et al., 2004: ${ }^{\circ}$ Adapted from Vincent et al., 2009.9 
and liver inflammation. Cholestatic jaundice due to hepatocellular and canalicular dysfunction may precede other signs of sepsis. Acute liver failure is rare and generally it is a consequence of the hemodynamic disorder secondary to prolonged shock, hypovolemia and decreased hepatic blood flow. Liver function tests return to normal with resolution of the infection. ${ }^{30}$ Gastrointestinal complications are to be related to motility disorder from hypoxic damage and inflammation and may occur with nausea, vomiting, diarrhea, and, alternatively, ileus generally reversible. ${ }^{31}$ Ischemic bowel necrosis may complicate prolonged shock. Upper gastrointestinal bleeding may be the manifestation of stress ulcer. ${ }^{32}$

\section{Adrenal cortex involvement}

In severe infection cortisol secretion is increased with loss of normal circadian rhythm. ${ }^{33,34}$ Stimulation of the hypothalamic-pituitary-adrenal axis is due to the action of high circulating levels of cytokines, which also determine tissue sensitization to cortisol. ${ }^{35}$ However, during the course of severe infection many factors tend to inhibit steroid response until steroid adrenal insufficiency. In septic patients is possible to observe adrenal hemorrhage and dysfunctions. Moreover elevated levels of inflammatory cytokines can directly inhibit cortisol synthesis and induce a systemic and tissue resistance to it. ${ }^{36}$ From a clinical point of view, adrenal insufficiency can be suggested in a septic patient who presents asthenia, anorexia, nausea, vomiting, diarrhea, confusion and a coexistent hemodynamic instability, ${ }^{37}$ hyponatremia, hyperkalemia and hypereosinophilia.

\section{Laboratory parameters}

Characteristically, a complete blood count may show normocytic anemia and leukocytosis (WBC $>12,000 / \mu \mathrm{L}$ ) associated with a left shift and evidence of bands; eventual leukopenia (WBC $<4000 / \mu L$ ) expresses a worse prognosis. Trombocytopenia (platelet $<50,000 / \mu \mathrm{L}$ ) has been observed in $10-30 \%$ of cases and reflects intravascular coagulation secondary to endothelial dysfunction. Thrombocytopenia, in association with other laboratory values as prolongation of the prothrombin time and the activated partial thromboplastin time, hypofibrinogenemia and antithrombin III deficiency, indicates ongoing disseminated intravascular coagulation. Blood smear may show the presence of schistocytes. ${ }^{38}$ Furthermore it might be detected hyperglycemia, more frequent in diabetic patients, which can evolve in ketoacidosis favored by hypotension; occasionally, hyperglycemia may be preceded by hypoglycemia, caused by an insufficient glycogenesis and an excessive insulin release. ${ }^{39}$

Serum albumin level declines for reduced hepatic synthesis and its dispersion in extravascular space. ${ }^{40}$
During early phase of sepsis, arterial blood gases show respiratory alkalosis, while in advanced sepsis it might be observed anion gap metabolic acidosis because of lactic acid accumulation. ${ }^{41}$

The electrocardiogram is not specific. Generally it shows sinus tachycardia and nonspecific ST-T wave abnormalities.

The chest radiography may show bilateral infiltrates caused by ALI or ARDS. ${ }^{42}$

\section{Diagnosis}

In patients with proven or suspected infections, diagnostically sensitive findings for sepsis are fever or hypothermia, tachycardia, tachypnea, leukocytosis or leukopenia; diagnosis is further suggested by an acutely altered mental status, thrombocytopenia, elevated blood lactate level, hypotension (Table 3). Definitive diagnosis requires isolation of the pathogen from blood sample or from the focus of infection. ${ }^{43} \mathrm{~A}$ proper blood culture requires a minimum of $10 \mathrm{~mL}$ of blood taken from different venipuncture sites. ${ }^{44}$ Positive results are detected earlier in Gram-positive bacteria cultures ( $\geq 24 \mathrm{~h}$ ) than in Gram-negative bacteria ones, which require longer incubation times (up to 7 days). Anyway, in many cases, blood cultures do not show any microbial growth. Culture of biological material from the primary site of infection or from infected cutaneous lesions, may be diagnostic.

Anyhow taking samples may not be simple, or the site of infection may be hidden. When indicated, it is necessary to send cerebrospinal fluid or samples taken from a central venous catheter or from other intravascular devices to the laboratory, in order to obtain a culture. Clinical detection of device-associated septicemia is difficult, at times. In patients with intravascular catheter, the rate of microbial growth in a culture of blood drawn through the catheter may be compared with that of blood drawn from a peripheral vein to assess the likelihood of catheter infection; a difference in the time to positivity of 2 or more hours suggests catheter infection. ${ }^{45}$

\section{Therapy}

Sepsis outcome depends on the time between clinical presentation and therapeutic intervention against infection and both hemodynamic and respiratory disorders, other than from the site of infection and comorbidities.

Antibiotic therapy has a better chance of success if started within an hour; ${ }^{46}$ mortality increases progressively for each hour of delay in starting appropriate antibiotic treatment, empirical against both Gram-positive and Gram-negative bacteria (Table 4). ${ }^{47,48}$ 
Table 3. Diagnostic criteria for sepsis.

Documented or suspected infection plus $\geq 1$ of the following

\section{General variables}

Fever or hypothermia (body temperature $>38.3^{\circ} \mathrm{C}$ or $<36^{\circ} \mathrm{C}$ )

Heart rate $(>90$ beats $/ \mathrm{min})$

Tachypnea $(>24$ breath $/ \mathrm{min})$

Altered mental status

Positive fluid balance ( $>20 \mathrm{~mL} / \mathrm{kg}$ of body weight over $24 \mathrm{~h}$ )

Hyperglycemia (plasma glucose $>120 \mathrm{mg} / \mathrm{dL}$ in patients without diabetes)

\section{Inflammatory variables}

Leukocytosis or leukopenia (white-cell count $>12,000 / \mathrm{mm}^{3}$ or $<4000 / \mathrm{mm}^{3}$ ) or $>10 \%$ bands

Plasma C-reactive protein $>2$ SD above the upper limit of the normal range

Plasma procalcitonin $>2$ SD above the upper limit of the normal range

\section{Hemodynamic variables}

Arterial systolic pressure $<90 \mathrm{mmHg}$ or mean arterial pressure

$<70 \mathrm{mmHg}$ or decrease in systolic pressure of $>40 \mathrm{mmHg}$

Mixed venous oxygen saturation $>70 \%$

Cardiac index $>3.5 \mathrm{~L} / \mathrm{min} / \mathrm{m}^{2}$ of body-surface area

\section{Organ-dysfunction variables}

$\mathrm{PaO}_{2} / \mathrm{FiO}_{2}<300$

Urine output $<0.5 \mathrm{~mL} / \mathrm{kg} / \mathrm{h}$ or $45 \mathrm{~mL} / \mathrm{h}$ at least $2 \mathrm{~h}$

Increase in creatinine level of $>0.5 \mathrm{mg} / \mathrm{dL}$

INR $>1.5$ or aPTT $>60 \mathrm{~s}$

Paralytic ileus (absence of bowel sounds)

Platelet count $<100,000 / \mathrm{mm}^{3}$

Plasma total bilirubin $>4 \mathrm{mg} / \mathrm{dL}$

Tissue-perfusion variables

Plasma lactate $>1 \mathrm{mmol} / \mathrm{L}$

Decrease capillary refill or mottling

INR, international normalized ratio; aPTT, activated partial thromboplastin time. Adapted from Levy et al., $2003 .{ }^{43}$

Table 4. Empiric antimicrobial therapy for sepsis.

\begin{tabular}{|c|c|c|c|}
\hline \multirow{2}{*}{$\begin{array}{l}\text { Clinical condition } \\
\text { Immunocompeted } \\
\text { adult }\end{array}$} & \multicolumn{2}{|c|}{ Antimicrobial regimens } & Bacterial pathogens \\
\hline & $\begin{array}{l}\text { Piperacillin/tazobactam, or* } \\
\text { Imipenem-cilastatin, or } \\
\text { Meropenem, or } \\
\text { Cefepime, or } \\
\text { Ceftazidime plus } \\
\text { Vancomycin, or } \\
\text { Teicoplanin }\end{array}$ & $\begin{array}{l}4.5 \mathrm{~g} \mathrm{q} 6 \mathrm{~h} \\
0.5 \mathrm{~g} \mathrm{q} 6 \mathrm{~h} \\
1 \mathrm{~g} \mathrm{q} 8 \mathrm{~h} \\
2 \mathrm{~g} \mathrm{q} 12 \mathrm{~h} \\
1 \mathrm{~g} \mathrm{q} 8 \mathrm{~h} \\
15 \mathrm{mg} / \mathrm{kg} \mathrm{q} 12 \mathrm{~h} \\
6 \mathrm{mg} / \mathrm{kg} \mathrm{q} 8 \mathrm{~h}, \text { then } \mathrm{q} 12 \mathrm{~h}\end{array}$ & $\begin{array}{l}\text { Community acquired Gram-negative bacteria } \\
\text { Staphylococcus aureus } \\
\text { Gram-positive cocci (Group A- } \beta \text { hemolitic } \\
\text { Streptococcus that produces pyrogenic exotoxin) }\end{array}$ \\
\hline Inpatient & $\begin{array}{l}\text { Piperacillin/tazobactam, or* } \\
\text { Imipenem-cilastatin, or } \\
\text { Meropenem, or } \\
\text { Cefepime, or } \\
\text { Ceftazidime plus } \\
\text { Amikacin, or } \\
\text { Ciprofloxacin, or } \\
\text { Levofloxacin plus } \\
\text { Vancomycin, or } \\
\text { Teicoplanin }\end{array}$ & $\begin{array}{l}4.5 \mathrm{~g} \mathrm{q} 6 \mathrm{~h} \\
0.5 \mathrm{~g} \mathrm{q} 6 \mathrm{~h} \\
1 \mathrm{~g} \mathrm{q} 8 \mathrm{~h} \\
2 \mathrm{~g} \mathrm{q} 12 \mathrm{~h} \\
1 \mathrm{~g} \mathrm{q} 8 \mathrm{~h} \\
15 \mathrm{mg} / \mathrm{kg} \mathrm{qd} \\
400 \mathrm{mg} \mathrm{q} 12 \mathrm{~h} \\
500-750 \mathrm{mg} \mathrm{q} 12 \mathrm{~h} \\
15 \mathrm{mg} / \mathrm{kg} \mathrm{q} 12 \mathrm{~h} \\
6 \mathrm{mg} / \mathrm{kg} \mathrm{q} 8 \mathrm{~h}, \text { then } \mathrm{q} 12 \mathrm{~h}\end{array}$ & $\begin{array}{l}\text { Gram-negative bacilli (Enterobacteriaceae, } \\
\text { Pseudomonas aeruginosa) } \\
\text { Staphylococcus aureus (MRSA) } \\
\text { Coagulase-negative Staphylococci }\end{array}$ \\
\hline $\begin{array}{l}\text { Neutropenic patient } \\
\text { (absolute neutrophil } \\
\text { count }<500 / \mu \mathrm{L})\end{array}$ & $\begin{array}{l}\text { Piperacillin/tazobactam, or* } \\
\text { Imipenem-cilastatin, or } \\
\text { Meropenem, or } \\
\text { Cefepime, or } \\
\text { Ceftazidime plus } \\
\text { Tobramycin }^{\circ} \text { plus } \\
\text { Caspofungin }\end{array}$ & $\begin{array}{l}4.5 \mathrm{~g} \mathrm{q} 6 \mathrm{~h} \\
0.5 \mathrm{~g} \mathrm{q} 6 \mathrm{~h} \\
1 \mathrm{~g} \mathrm{q} 8 \mathrm{~h} \\
2 \mathrm{~g} \mathrm{q} 12 \mathrm{~h} \\
1 \mathrm{~g} \mathrm{q} 8 \mathrm{~h} \\
5-7 \mathrm{mg} / \mathrm{kg} \mathrm{qd} \\
70 \mathrm{mg} \text { loading dose then } 50 \mathrm{mg} \mathrm{qd}\end{array}$ & $\begin{array}{l}\text { Gram-negative bacilli (E. coli, Klebsiella spp., } \\
\quad \text { Pseudomonas spp.) } \\
\text { Enterococcus (E. faecium, E. faecalis) } \\
\text { Gram-positive cocci (MRSA, MR-Coagulase- } \\
\quad \text { negative Staphylococci) }\end{array}$ \\
\hline $\begin{array}{l}\text { Splenectomized } \\
\text { patient }\end{array}$ & $\begin{array}{l}\text { Cefotaxime, or } \\
\text { Ceftriaxone, or } \\
\text { Cefepime }\end{array}$ & $\begin{array}{l}2 \mathrm{~g} \mathrm{q} 6-8 \mathrm{~h} \\
2 \mathrm{~g} \mathrm{q} 12 \mathrm{~h} \\
2 \mathrm{~g} \mathrm{q} 12 \mathrm{~h}\end{array}$ & $\begin{array}{l}\text { Streptococcus pneumoiae } \\
\text { Klabsiella pneumoniae } \\
\text { Haemophilus influenzae } \\
\text { Neisseria meningitidis }\end{array}$ \\
\hline Addicted patient & $\begin{array}{l}\text { Vancomycin, or } \\
\text { Teicoplanin, or } \\
\text { Oxacillin plus } \\
\text { Gentamicin }\end{array}$ & $\begin{array}{l}15 \mathrm{mg} / \mathrm{kg} \mathrm{q} 12 \mathrm{~h} \\
6 \mathrm{mg} / \mathrm{kg} \mathrm{q} 8 \mathrm{~h}, \text { then } \mathrm{q} 12 \mathrm{~h} \\
2 \mathrm{~g} \mathrm{q} 6 \mathrm{~h} \\
3-5 \mathrm{mg} / \mathrm{kg} \mathrm{qd}\end{array}$ & $\begin{array}{l}\text { Staphylococcus aureus (MRSA) } \\
\text { Gram-negative bacilli§ }\end{array}$ \\
\hline
\end{tabular}

*If the patient is allergic to $\beta$-lactam drugs, use ciprofloxacin or levofloxacin plus clindamycin; ${ }^{\circ}$ add vancomycin or teicoplanin if the patient: i) has an indwelling vascular catheter, ii) has received quinolone prophylaxis, iii) has received chemotherapy that produces mucosal damage; \#add antifungal therapy if the patient is hypotensive or has been receiving broad-spectrum antibacterial drugs; ${ }^{\S}$ also consider Candida spp. 
Antibiotic monotherapy is not inferior to antibiotic combination therapy, which is indicated only in sepsis associated with neutropenia or caused by Pseudomonas $s p p$; in these latter cases aminoglycoside monotherapy is less effective than its association with an antipseudomonal $\beta$-lactam antibiotic (cefepime, ceftazidime, piperacillin-tazobactam, meropenem). ${ }^{49,50}$ Antifungal therapy should be used only in patients at high risk for invasive candidiasis (septic patient who has received broad-spectrum antibiotics and parenteral nutrition, or who has been neutropenic for more than 5 days, or who has had long-term central venous catheter, or who has been hospitalized in an Intensive Care Unit for a prolonged period).$^{51}$

After the first six hours, organic functions have to be revalued and de-escalation of the initial antibiotic therapy have to be considered, with the aim of preventing multi-drug-resistant organism emergency, reducing drug toxicity risk and costs. ${ }^{52}$

Most of the patients requires antibiotics for at least a week. Treatment's duration is usually influenced by the site of tissue infection, the adequacy of surgical drainage, the patient's underlying disease, the antimicrobial susceptibility of the bacterial agent. ${ }^{53}$

Table 5. Treatment of severe sepsis and septic shock - interventions to restore perfusion, respiratory support, general supportive care.

Interventions to restore perfusion

Begin goal-directed resuscitation during first $6 \mathrm{~h}$ after recognition

Begin initial fluid resuscitation with crystalloid and consider the addition of albumin

Consider the addition of albumin when substantial amounts of crystalloid are required to maintain appropriate arterial pressure

Avoid hetastarch formulations

Begin initial fluid challenge ( $\geq 30 \mathrm{~mL}$ of crystalloids per kilogram of body weight) in patients with tissue hypoperfusion and suspected hypovolemia

Continue fluid-challenge technique as long as there is hemodynamic improvement

Use norepinephrine as the first-choice vasopressor (MAP $\geq 65 \mathrm{mmHg}$ )

If an additional agent is needed, use epinephrine

Add vasopressin (at a dose of 0.03 units/min) when weaning of norepinephrine, if tolerated

Avoid the use of dopamine except in carefully selected patients (e.g., patients with a low risk of arrhythmias and either known marked left ventricular systolic dysfunction or low heart rate)

Infuse dobutamine or add it to vasopressor therapy in the presence of myocardial dysfunction (e.g., elevated cardiac filling pressure or low cardiac output) or ongoing hypoperfusion despite adequate intravascular volume and mean arterial pressure

Avoid the use of intravenous hydrocortisone if adequate fluid resuscitation and vasopressor therapy restore hemodynamic stability; if hydrocortisone is used, administer at dose of $200 \mathrm{mg}$ /day

Target a hemoglobin level of 7 to $9 \mathrm{~g} / \mathrm{dL}$ in patients without hypoperfusion, critical coronary artery disease or myocardial ischemia, or acute hemorrhage

\section{Respiratory support}

Use a low tidal volume and limitation of inspiratory-plateau-pressure strategy for ARDS

Apply a minimal amount of positive end-expiratory pressure in ARDS

Administer higher rather than lower positive end-expiratory pressure for patients with sepsis-induced ARDS

Use recruitment maneuvers in patients with severe refractory hypoxemia due to ARDS

Use prone positioning in patients with sepsis-induced ARDS and a ratio of the partial pressure of arterial oxygen (mmHG) to the fraction of inspired oxygen of $<100$, in facilities that have experience with such practices

Elevate the head of the bed in patients undergoing mechanical ventilation, unless contraindicated

Use a conservative fluid strategy for established acute lung injury or ARDS with no evidence of tissue hypoperfusion

Use weaning protocol

\section{General supportive care}

Use a protocol-specified approach of blood glucose management, with the initiation of insulin after two consecutive blood glucose level of $>180 \mathrm{mg} / \mathrm{dL}$, targeting a blood glucose level of $<180 \mathrm{mg} / \mathrm{dL}$

Use the equivalent of continuous veno-venous hemofiltration or intermittent hemodialysis as needed for renal failure or fluid overload

Administer prophylaxis for deep vein thrombosis

Administer stress-ulcer prophylaxis to prevent upper gastrointestinal bleeding

Administer oral or enteral feedings, as tolerated, rather than either complete fasting or provision of only intravenous glucose within the first $48 \mathrm{~h}$ after a diagnosis of severe sepsis or septic shock

Address goals of care (treatment plans and end-of-life planning)

MAP, mean arterial pressure; ARDS, acute respiratory distress syndrome. Adapted from Dellinger et al., $2013 .{ }^{2}$ 


\section{Treatment of hemodynamic disorder}

Treatment of hemodynamic disorder is essential to re-establish tissue perfusion and recuperate organ damages. Cardiocirculatory resuscitation (Table 5) requests infusion of crystalloid (normal saline) with an initial bolus dose of $30 \mathrm{~mL} / \mathrm{kg}$, in 1-2 h. However, in order to avoid eventual hyperchloremic acidosis, it is possible to alternate normal saline with Ringer's lactate. To avoid pulmonary edema, the central venous pressure should be maintained between $12-18 \mathrm{~cm}$ $\mathrm{H}_{2} \mathrm{O}$, and diuresis should be kept at $>0.5 \mathrm{~mL} / \mathrm{kg} / \mathrm{h}$ by continuing fluid administration and, if necessary, adding furosemide.

In about one-third of patients, hypotension and organ hypoperfusion respond to this treatment (SBP $>90 \mathrm{mmHg}, \mathrm{MAP}>65 \mathrm{mmHg}$ ). If fluid resuscitation has not been sufficient, vasopressor therapy is recommended (Table 5) ${ }^{54}$ Norepinephrine should be the firstchoice. Dopamine is not recommended because it may promote the onset of cardiac arrhythmias. ${ }^{55}$ If necessary, another vasopressor (epinephrine or vasopressin) may be added. Dobutamine is recommended if ongoing signs of hypoperfusion are present, despite adequate fluid therapy and initial vasopressors administration. ${ }^{52,53}$

In patients with refractory hypotension the administration of hydrocortisone ( $50 \mathrm{mg} \mathrm{q} 6 \mathrm{~h}$ ) has to be considered; if clinical improvement occurs within 24-48 $\mathrm{h}$, this treatment may be continued for 5-7 days before slowly tapering and discontinuing it. ${ }^{2}$

Red blood cells transfusion is recommended if hemoglobin concentration is $\leq 7 \mathrm{~g} / \mathrm{dL}$ with a target level of $9 \mathrm{~g} / \mathrm{dL}$, unless ischemic coronary artery disease, acute hemorrhage or severe hypoxemia are present. ${ }^{56}$ Erythropoietin is not recommended to treat sepsis-related anemia.

\section{Respiratory support}

Ventilator therapy is indicated for progressive hypoxemia, hypercapnia, neurologic deterioration or respiratory muscles failure (Table 5). Tachypnea is an indicator of forthcoming respiratory collapse (respiratory rate $>30$ breaths $/ \mathrm{min}$ ).

\section{General supportive care}

Septic patients may experience protein hypercatabolism and AKI, which may require intermittent hemodialysis and continuous veno-venous hemofiltration. However, nutritional supplement (enteral or parenteral) can reduce protein hypercatabolism (Table 5).

Prophylactic heparinization is indicated to prevent deep venous thrombosis in patients without active bleeding; if heparin is contraindicated, compression stockings or an intermittent compression device should be useful.
Insulin should be used to keep blood glucose levels $<180 \mathrm{mg} / \mathrm{dL}$ (and at about $150 \mathrm{mg} / \mathrm{dL}$ ), but it is necessary to monitor the patient in order to avoid the risk of hypoglycemia.

\section{Other therapies}

Even if using activated protein $\mathrm{C}$ increases bleeding risk, its use has shown an improved survival within 28 days in septic patients with an APACHE II (acute physiology and chronic health evaluation II) score $\geq 25 .{ }^{57}$

\section{References}

1. Bone RC, Balk RA, Cerra FB, et al. Definitions for sepsis and organ failure and guidelines for the use of innovative therapies in sepsis. Chest 1992;101:1644-55.

2. Dellinger RP, Levy MM, Rhodes A, et al. International guidelines for management of severe sepsis and septic shock: 2012. Crit Care Med 2013;41:580-637.

3. Cawcutt KA, Peters SG. Severe sepsis and septic shock: clinical overview and update on management. Mayo Clin Proc 2014;89:1572-8.

4. Salvo I, De Cian W, Nusicco M, et al. The Italian SEPSIS study: preliminary results on the incidence and evolution of SIRS, sepsis, severe sepsis and septic shock. Intensive Care Med 1995;21:S244-9.

5. Malacarne P, Boccalatte D, Acquarolo A, et al. Epidemiology of nosocomial infection in 125 italian intensive care units. Minerva Anestesiol 2010;76:13-23.

6. Angus DC, Linde-Zwirble WT, Lidicker J, et al. Epidemiology of severe sepsis in the United States: analysis of incidence, outcome, and associated costs of care. Crit Care Med 2001;29:1303-10.

7. Lagu T, Rothberg MB, Shieh MS, et al. Hospitalizations, costs, and outcomes of severe sepsis in the United States 2003 to 2007. Critical Care Med 2012;40:754-5.

8. van Gestel A, Bakker J, Veraart CP, et al. Prevalence and incidence of severe sepsis in dutch intensive care units. Crit Care 2004;8:R153-62.

9. Vincent JL, Rello J, Marshall J, et al. International study of the prevalence and outcomes of infection in intensive care units. JAMA 2009;302:2323-9.

10. Sands KE, Bates DW, Lanken PN, et al. Epidemiology of sepsis syndrome in 8 academic medical centers. JAMA 1997;278:234-40.

11. Richards MJ, Edwards JR, Culver DH, et al. Nosocomial infections in combined medical-surgical intensive care units in the United States. Infect Control Hosp Epidemiol 2000;21:510-5.

12. Kingston ME, Mackey D. Skin clues in the diagnosis of life-threatening infections. Rev Infect Dis 1986;8:1-11.

13. Ranieri VM, Thompson BT, Barie PS, et al. Drotrecogin alfa (activated) in adults with septic shock. N Engl J Med 2012;366:2055-64.

14. Opal SM, Garber GE, LaRosa SP, et al. Systemic host responses in severe sepsis analyzed by causative microorganism and treatment effects of drotrecogin alfa (activated). Clin Infect Dis 2003;37:50-8.

15. van der Poll T, Opal SM. Host-pathogen interactions in sepsis. Lancet Infect Dis 2008;8:32-43. 
16. Levi M, van der Poll T. Inflammation and coagulation. Crit Care Med 2010;38:S26-34.

17. Angus DC, van der Poll T. Critical care medicine: severe sepsis and septic shock. N Engl J Med 2013;369:840-51.

18. Rosas-Ballina M, Olofsson PS, Ochani M, et al. Acetylcholine-synthesizing $\mathrm{T}$ cells relay neural signals in a vagus nerve circuit. Science 2011;334:98-101.

19. Boomer JS, To K, Chang KL, et al. Immunosuppression in patients who die of sepsis and multiple organ failure. JAMA 2011;306:2594-605.

20. Torgersen C, Moser P, Luckner G, et al. Macroscopic postmortem findings in 235 surgical intensive care patients with sepsis. Anesth Analg 2009;108:1841-7.

21. Bolton CF, Young GB, Zochodne DW. The neurological complications of sepsis. Ann Neurol 1993;33:94-100.

22. Reiss MA. Toxic shock syndrome. Prim Care Update Ob Gyns 2000;7:85-90.

23. Kingston ME, Mackey D. Skin clues in the diagnosis of life-threatening infections. Rev Infect Dis 1986;8:1-11.

24. Warren HS. Strategies for the treatment of sepsis. N Engl J Med 1997;336:952-53.

25. Silverman HJ, Penaranda R, Orens JB, et al. Impaired beta-adrenergic receptor stimulation of cyclic adenosine monophosphate in human septic shock: association with myocardial hyporesponsiveness to catecholamines. Crit Care Med 1993;21:31-9.

26. Abraham E, Matthay MA, Dinarello CA, et al. Consensus conference definitions for sepsis, septic shock, acute lung injury, and acute respiratory distress syndrome: time for a reevaluation. Crit Care Med 2000;28:232-5.

27. Sessler CN, Bloomfield GL, Fowler AA. Current concepts of sepsis and acute lung injury. Clin Chest Med 1996; 17:213-35

28. Bulfoni A, Concia E, Costantino S, et al. Orientamenti terapeutici per il trattamento delle sepsi e delle endocarditi in Medicina Interna. Ital J Int Med 2004;3:S1/S2-31.

29. Thijs A1, Thijs LG. Pathogenesis of renal failure in sepsis. Kidney Int Suppl 1998;66:S34-7.

30. Pirovino M, Meister F, Rubli E, et al. Preserved cytosolic and synthetic liver function in jaundice of severe extrahepatic infection. Gastroenterology 1989;96:1589-95.

31. Tasaki K, Sasaki M, Bamba M, et al. A case of toxic shock-like syndrome presenting with serious hypoproteinaemia because of a protein-losing gastroenteropathy. J Intern Med 2001;250:174-9.

32. Haglund U. Stress ulcers. Scand J Gastroenterol Suppl 1990;175:27-33.

33. Barton RN, Stoner HB, Watson SM. Relationships among plasma cortisol, adrenocorticotrophin, and severity of injury in recently injured patients. J Trauma 1987; 27:384-92.

34. Chernow B, Alexander HR, Smallridge RC, et al. Hormonal responses to graded surgical stress. Arch Intern Med 1987;147:1273-8.

35. Chrousos GP. The hypothalamic-pituitary-adrenal axis and immune-mediated inflammation. N Engl J Med 1995;332:1351-62.

36. Catalano RD, Parameswaran V, Ramachandran J, et al. Mechanisms of adrenocortical depression during Escherichia coli shock. Arch Surg 1984;119:145-50.

37. Lamberts SW, Bruining HA, de Jong FH. Corticosteroid therapy in severe illness. N Engl J Med 1997; 337:1285-92.
38. Levi M, Keller TT, van Gorp E, et al. Infection and inflammation and the coagulation system. Cardiovasc Res 2003;60:26-39.

39. McCowen KC, Malhotra A, Bistrian BR. Stress-induced hyperglycemia. Critical Care Clin 2001;17: 107-24.

40. Harris RL, Musher DM, Bloom K, et al. Manifestations of sepsis. Arch Intern Med 1987;147:1895-906.

41. Gore DC, Jahoor F, Hibbert JM, et al. Lactic acidosis during sepsis is related to increased pyruvate production, not deficits in tissue oxygen availability. Ann Surg 1996;224:97-102.

42. Matthay MA1, Zimmerman GA, Esmon C, et al. Future research directions in acute lung injury: summary of a national heart, lung, and blood institute working group. Am J Respir Crit Care Med 2003;167:1027-35.

43. Levy MM, Fink MP, Marshall JC, et al. 2001 SCCM/ ESICM/ACCP/ATS/SIS International sepsis definitions conference. Crit Care Med 2003;31:1250-6.

44. Lamy B, Roy P, Carret G, et al. What is the relevance of obtaining multiple blood samples for culture? A comprehensive model to optimize the strategy for diagnosing bacteremia. Clin Infect Dis 2002;35:842-50.

45. Gaur AH, Flynn PM, Giannin MA, et al. Difference in time to detection: a simple method to differentiate catheter-related from non-catheter-related bloodstream infection in immunocompromised pediatric patients. Clin Infect Dis 2003;37:469-75.

46. Gaieski DF, Mikkelsen ME, Band RA, et al. Impact of time to antibiotics on survival in patients with severe sepsis or septic shock in whom early goal-directed therapy was initiated in the emergency department. Crit Care Med 2010;38:1045-53.

47. Paul M, Shani V, Muchtar E, et al. Systematic review and meta-analysis of the efficacy of appropriate empiric antibiotic therapy for sepsis. Antimicrob Agents Chemother 2010;54:4851-63.

48. Kumar A, Roberts D, Wood KE, et al. Duration of hypotension before initiation of effective antimicrobial therapy is the critical determinant of survival in human septic shock. Crit Care Med 2006;34:1589-96.

49. Brunkhorst FM, Oppert M, Marx G, et al. Effect of empirical treatment with moxifloxacin and meropenem vs meropenem on sepsis-related organ dysfunction in patients with severe sepsis: a randomized trial. JAMA 2012;307:2390-9.

50. Paul M, Benuri-Silbiger I, Soares-Weiser K, et al. Beta lactam monotherapy versus beta lactam-aminoglycoside combination therapy for sepsis in immunocompetent patients: systematic review and meta-analysis of randomised trials. BMJ 2004;328:668.

51. Bochud PY, Bonten M, Marchetti O, et al. Antimicrobial therapy for patients with severe sepsis and septic shock: an evidence-based review. Crit Care Med 2004;32: S495-512.

52. Heenen S, Jacobs F, Vincent JL. Antibiotic strategies in severe nosocomial sepsis: why do we not de-escalate more often? Crit Care Med 2012;40:1404-9.

53. Dellinger RP, Levy MM, Carlet JM. Surviving sepsis campaign: international guidelines for management of severe sepsis and septic shock: 2008. Crit Care Med 2008;36:296.

54. Kollef MH, Micek ST. Severe sepsis and septic shock. 
In: Kollef MH, Isakow W, eds. The Washington manualTM of critical care. Philadelphia: Lippincott Williams \& Wilkins; 2013. pp 8-13.

55. De Backer D, Biston P, Devriendt J, et al. Comparison of dopamine and norepinephrine in the treatment of shock. N Engl J Med 2010;362:779-89.
56. Holst LB, Haase N, Wetterslev J, et al. Lower versus higher hemoglobin threshold for transfusion in septic shock. N Engl J Med 2014;371:1381-91.

57. Bernard GR, Vincent JL, Laterre PF, et al. Efficacy and safety of recombinant human activated protein $\mathrm{C}$ for severe sepsis. N Engl J Med 2001;344:699-709. 